\title{
DiscoverArchive
}

Retrieved from DiscoverArchive,

Vanderbilt University's Institutional Repository

Published as Gray proctor and Nancy J. King, Post Padilla: Padilla's Puzzles for

Review in State and Federal Courts in 23 Fed. Sent. R. 239 2011. (C) 2011 by the Regents of the University of California. Copying and permissions notice: Authorization to copy this content beyond fair use (as specified in Sections 107 and 108 of the U. S. Copyright Law) for internal or personal use, or the internal or personal use of specific clients, is granted by the Regents of the University of California for libraries and other users, provided that they are registered with and pay the specified fee via Rightslink ${ }^{\circledR}$ on JSTOR (http://www.jstor.org/r/ucal) or directly with the Copyright Clearance

Center, http://www.copyright.com. 


\section{Post Padilla: Padilla's Puzzles for Review in State and Federal Courts}

\section{Introduction}

Federal law provides that noncitizens convicted of designated crimes may be deported from the country, barred from returning, and denied the opportunity to become United States citizens. Prior to the Supreme Court's decision in Padilla v. Kentucky, ${ }^{\mathrm{I}}$ lower courts disagreed over whether and when a lawyer's deficient advice about the deportation consequences of conviction violated a defendant's constitutional right to the effective assistance of counsel. Only three state courts had interpreted the Sixth Amendment to impose a duty on defense counsel to provide advice about the risks of deportation to clients who are pleading guilty. ${ }^{2}$ All federal courts of appeals and most state courts had concluded that counsel had no constitutional duty to advise a defendant about the collateral consequences of conviction, including deportation. ${ }^{3}$ Most of these jurisdictions nevertheless made an exception for affirmative misadvice by counsel. ${ }^{4}$

Then came the Padilla decision. Jose Padilla, a Honduran national who had been a lawful permanent resident of the United States for more than forty years, pleaded guilty to smuggling marijuana, allegedly relying on counsel's assurance that he would not be deported as a result. Padilla's counsel was wrong, and deportation proceedings ensued. On state postconviction review, the Supreme Court of Kentucky rejected Padilla's ineffective assistance claim, explaining that deportation was a collateral consequence of conviction and that defense attorneys had no duty under the Sixth Amendment to advise their clients about collateral consequences.

The U.S. Supreme Court reversed, deciding that the Sixth Amendment guarantee of effective counsel requires competent advice about the deportation consequences of a guilty plea. Although Padilla himself had received misleading advice, the Court did not limit its holding to affirmative misrepresentations. Instead, the Court held that the right to effective counsel, as interpreted in Strickland v. Washington ${ }^{5}$ and Hill v. Lockhart, ${ }^{6}$ requires advice about deportation that would be "reasonable under prevailing professional norms."7 Thus, failure to provide any advice about deportation may be as unreasonable as faulty advice when the immigration consequences are clear.
The Court also remarked that the distinction between direct and collateral consequences developed in a line of cases that defined the due process requirements for a knowing plea of guilty, and that "we have never applied the direct/collateral distinction to a sixth amendment claim." ${ }^{8}$ Instead, the Court explained that

deportation is intimately related to the criminal process, which makes it uniquely difficult to classify as either a direct or a collateral consequence. Because that distinction is thus ill suited to evaluating a Strickland claim concerning the specific risk of deportation, advice regarding deportation is not categorically removed from the ambit of the Sixth Amendment right to counsel. ${ }^{9}$

The decision in Padilla has potentially far-reaching consequences. More than I28,000 noncitizens with criminal convictions were deported in 2009. Approximately 95,000 noncitizens were incarcerated in state and federal prisons and jails as of June 30, 2009. ${ }^{\text {I0 }}$ An unknown proportion of deportees and prisoners who face deportation will bring Padilla claims. And because the Court in Padilla interpreted the Sixth Amendment to provide greater protection for defendants than most jurisdictions previously had recognized, ${ }^{\mathrm{II}}$ many will be raising their claims for the first time years after they were convicted, or for a second time, having already lost the same claim in state or federal court.

This article addresses the many issues facing the state and federal courts that must resolve these claims. ${ }^{\mathrm{I} 2}$ Fears that the Supreme Court's latest pronouncement will strain the resources of the lower judiciary by triggering a flood of hearings and retrials, we believe, are unfounded. Instead, most Padilla claims will be rejected, either because of procedural restrictions on state and federal postconviction review, or because the claimant was not prejudiced by counsel's actions.

\section{When a Padilla Claim May Be Raised}

Most defendants will be raising their Padilla claims in the postconviction context, where they will face the many barriers to review that we discuss in part IV of this article. A

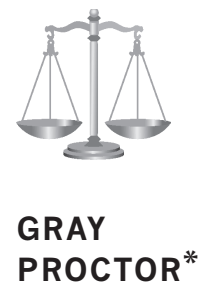

Staff Attorney, Fourth Circuit Court of Appeals

\section{NANCY KING**}

Speir Professor of Law, Vanderbilt University Law School

Federal Sentencing Reporter, Vol. 23, No. 3, pp. 239-249, ISSN I053-9867 electronic ISSN I533-8363. (C) 20II Vera Institute of Justice. All rights reserved. Please direct requests for permission to photocopy or reproduce article content through the University of California Press's Rights and Permissions website, http://www.ucpressjournals.com/reprintInfo.asp. DOI: I0.I525/fsr.20II.23.3.239. 
defendant can avoid these obstacles to relief by bringing his claims at the trial level. Few defendants will enjoy this opportunity, however. A defendant might attempt to file a motion to withdraw his guilty plea in the trial court, but such motions must be filed by substitute counsel, and before sentencing. ${ }^{33}$ Some jurisdictions authorize review of counsel's performance in a motion in arrest of judgment, but the window of opportunity to file such motions can be quite short. ${ }^{\mathrm{I}}$

Most Padilla claims will be unreviewable on direct appeal as well. ${ }^{15}$ Generally, defendants must postpone raising ineffective assistance claims until postconviction proceedings, when an evidentiary hearing can be held if necessary. ${ }^{16}$ An exception exists for claims already apparent in the record. ${ }^{17}$ Additionally, some states require a known claim of ineffective assistance to be raised on direct appeal if the appellant is represented by new counsel, but if factual development is necessary, courts tend not to remand for a hearing during the direct appeal. ${ }^{\mathrm{I} 8}$ Instead, most Padilla claims will be reviewed after direct review is complete, in state and federal postconviction proceedings.

\section{Express Waivers of Review}

Waiver provisions are increasingly common in plea agreements. Although some purport to waive any legal challenge to either the conviction or sentence in appeal or postconviction proceedings, ${ }^{\mathrm{I}}{ }^{9}$ these provisions are not valid as to claims which, like Padilla, attack the validity of the plea agreement itself. ${ }^{20}$ In several jurisdictions, courts refuse to uphold all waivers of the right to raise ineffective assistance claims, and in some states rules of professional conduct ban as unethical all such waivers. ${ }^{2 \mathrm{I}}$ Where courts have found such claims waived, the attorney's ineffectiveness did not implicate the voluntariness of the plea.

\section{Padilla on Postconviction Review}

Because of the relatively complex procedures attendant to postconviction review, prisoners raising Padilla claims in collateral proceedings face several additional barriers to relief.

\section{A. Retroactive Application and Teague}

The first wave of Padilla claimants will have to show that Padilla applies to criminal judgments that were final before it was issued. In Teague v. Lane, ${ }^{22}$ the Supreme Court held that ordinarily, federal habeas courts may not apply "new" rules of constitutional criminal procedure announced only after the state courts had reviewed the prisoner's case. The ban on the consideration of such socalled new rules is also applied by federal courts when reviewing collateral challenges to federal criminal judgments under $\ 2255$, and by many state courts as a limitation in their own state postconviction proceedings. ${ }^{23}$

In Teague itself, Justice Sandra O'Connor wrote that a new rule generally "breaks new ground or imposes a new obligation on the States or the Federal Government. To put it differently, a case announces a new rule if the result was not dictated by precedent existing at the time the defendant's conviction became final." 24 Teague also bars retroactive application of settled law to a new context. ${ }^{25}$ Subsequent decisions evince a broad definition of new, including at times decisions that resolve any issue "susceptible to debate among reasonable minds." ${ }^{26} \mathrm{Nev}$ ertheless, the Justices have also stated that "the standard for determining when a case establishes a new rule is 'objective,' and the mere existence of conflicting authority does not necessarily mean a rule is new." 27 And a line of authority emphasizes that specific applications of rules of general applicability, particularly the rule in Strickland, do not create new rules. ${ }^{28}$

Because the Supreme Court in Padilla had no need to discuss retroactivity, the issue remains open. Opponents of retroactive application of Padilla will emphasize that only three state courts (and no federal courts) had endorsed the position adopted by the majority in Padilla, so the decision clearly effected an abrupt change in the legal landscape. The sheer volume of precedent to the contrary would indicate a novel rule under some formulations of the rule in Teague. ${ }^{29}$ Nearly every lower court to address the issue has, however, determined that Padilla is not a new rule, ${ }^{3 \circ}$ and we agree.

In Padilla, the Court clearly applied Strickland, finding deficiency solely with reference to prevailing professional norms. Accordingly, lower courts appropriately characterize the decision as applying "a well-established rule of law in a new way based on the specific facts of a particular case." ${ }^{1}$ The Court in Padilla relied on an unqualified application of the well-known standard that it had first announced in Strickland in I984 and applied to guilty pleas in Hill in I985. Padilla merely reiterates that no shorthand version or alternative test-such as one that distinguishes between collateral and direct consequences of conviction-can serve as a substitute. In other words, Padilla is like other Strickland progeny that apply retroactively. ${ }^{32}$

Two other statements suggest that the Court will determine that Padilla is not a new rule. In 200I, the Court observed in dicta that all reasonably competent counsel would advise their clients about the immigration consequences of a guilty plea. ${ }^{33}$ Additionally, the Padilla opinion itself suggests retroactivity. Appearing as amicus, the United States argued that requiring counsel to do more than avoid affirmative misadvice "could strain judicial and prosecutorial resources" because most "defendants would likely not challenge their pleas until years later, when the collateral consequences of the conviction first become evident," leading to "an influx of challenges to long-final pleas." 34 The Court stated that "it had 'given serious consideration' to the argument that its ruling would open the 'floodgates' to new litigation challenging prior guilty pleas." 35 Without a mention of Teague, the Court explained that its decision would not likely affect the finality of most convictions for two reasons: (I) because presumably counsel have fulfilled their duty under prevailing norms of 
professional conduct to provide their clients with immigration advice and (2) because few prisoners will risk losing the benefits of their plea bargains. ${ }^{36}$

If the weight of emerging authority is wrong, and Padilla is a new rule of criminal procedure under Teague, it almost certainly falls outside the extremely narrow exception for watershed rules that implement previously unrecognized "bedrock procedural elements essential to the fairness of a proceeding," and protect against an "impermissibly large risk of an inaccurate conviction."37 The Supreme Court has never found a new rule to be of this magnitude, and has instead intimated repeatedly that only Gideon itself qualifies..$^{3}$

In state postconviction proceedings, federal Teague jurisprudence does not determine retroactivity, although it is often relevant. In Danforth v. Minnesota, 39 the Supreme Court decided that states are free to apply retroactively a broader class of rules of constitutional criminal procedure than that defined in Teague..$^{\circ}$ Some states have explicitly done so, whereas others have adopted Teague or specific progeny to limit state postconviction review. ${ }^{4 \mathrm{I}}$

\section{B. Statute of Limitations for Filing}

Waiver clauses and retroactivity analysis should not bar Padilla claims, but filing deadlines might. Federal (and many state) statutes limit the time period for seeking collateral review. A federal petitioner has one year to file his claims, beginning on the date the judgment becomes final. ${ }^{2}$ Although a majority of states have similar limitations periods, some lack them entirely or follow a more flexible laches approach that resembles pre-AEDPA 43 federal law. 44 Many petitioners will raise Padilla claims only after these deadlines elapse, often because counsel's error became apparent only after immigration proceedings commenced.

Several provisions of federal law allow a belated commencement of the statute of limitations. These provisions, however, are unlikely to apply to Padilla claims. One such provision commences the limitations period on "the date on which the [new] right asserted was initially recognized by the Supreme Court, if that right has been newly recognized by the Supreme Court and made retroactively applicable to cases on collateral review." 45 As we have argued in this article, Padilla is not a newly recognized rule at all. Even if Padilla were a so-called new rule, this section could not apply until the Supreme Court determined that Padilla applied retroactively. Because the right would have been initially recognized on the day Padilla issued, the Court would have to issue its retroactivity decision by March 31, 20II. ${ }^{4}$ Even if such a swift resolution were possible, Padilla fails to satisfy either of the exceptions that would allow it to be made retroactively applicable. 47

Another provision delays the beginning of the one-year filing clock if the "factual predicate of" (for state prisoners) or "facts supporting" (for federal prisoners) "the claim ... presented could not have been discovered earlier through the exercise of due diligence." ${ }^{8}$ This provision applies, for example, when a prisoner files her claim promptly after learning that counsel successfully concealed a serious conflict of interest. Padilla claims, however, do not rely on facts discoverable only after a conviction becomes final. Every defendant has firsthand knowledge of the advice she received from her lawyer before pleading guilty, and most defendants will know at that time whether they are United States citizens. The subsequent discovery of an immigration consequence is not a fact, but is instead a question of law, similar to the application of sentencing statutes, rules, and guidelines. Advice about immigration consequences is either unreasonable when delivered or it is not; it does not become unreasonable only after removal is imminent.

In rare cases, courts may invoke the doctrine of equitable tolling to excuse a late filing. In Holland v. Florida,49 the Supreme Court joined every lower federal court in recognizing that equitable tolling of the statute of limitations is theoretically available where an "extraordinary circumstance" impeded timely filing and the petitioner had been pursuing his rights diligently..$^{\circ}$ The Eleventh Circuit had held that attorney error during habeas proceedings, where no right to counsel applies, could not justify equitable tolling absent "bad faith, dishonesty, divided loyalty, mental impairment or so forth." ${ }^{51}$ The Supreme Court reversed, holding that egregiously negligent behavior by an attorney could constitute exceptional circumstances justifying equitable tolling.

Padilla claimants are no more likely than others to demonstrate entitlement to equitable tolling under $\mathrm{Hol}$ land..$^{2}$ Deficient, even egregious advice given at the plea stage does not directly impair the subsequent filing of a postconviction petition. ${ }^{53}$ Moreover, nothing in the Court's opinion is inconsistent with the conclusion of lower courts that the inability to speak English can justify tolling only where the prisoner also shows diligent efforts to obtain translation assistance. 54

\section{Padilla Claims Raised in Second or Successive Petitions}

Petitioners raising Padilla claims in a second petition face yet another barrier to review. Federal courts may not entertain a new claim in a second or successive petition unless the claim meets one of two very narrow exceptions, neither of which fit a Padilla claim. ${ }^{55}$ First, a second petition is permitted if it relies on "a new rule of constitutional law, made retroactive to cases on collateral review by the Supreme Court, that was previously unavailable." ${ }^{56}$ As explained previously, Padilla likely does not establish a new rule of constitutional law, and if it does, it is a rule that will almost certainly not apply retroactively. 57 Likewise, the exception permitting a second petition if the claim relies on facts that could not have been discovered sooner will be as useless to a petitioner who omits his Padilla claim from his first petition as it is to a petitioner 
whose first petition is untimely. On top of that, an admission of guilt in open court will generally belie subsequent claims that "no reasonable factfinder would have found the applicant guilty of the underlying offense." 58

What of the petitioner whose claim was properly raised in the first petition, only to be rejected in violation of Padilla? In this situation, the federal statute bars relief, providing only one opportunity for federal review. 59

\section{Procedural Default: Failure to Raise Padilla Claim Earlier}

Generally, the defense of procedural default ${ }^{60}$ bars postconviction relief in state or federal court for claims that the petitioner failed to raise correctly in earlier proceedings. Unless a state requires ineffective assistance of counsel claims to be raised on appeal, petitioners must raise their Padilla claims in their first postconviction petitions. Thus, procedural default should not affect federal prisoners who raise their Padilla claims in their first $\int 2255$ motions, or most state prisoners who raise their Padilla claims in their first state postconviction petitions.

Where it does apply, procedural default is excused if the petitioner can show either (I) cause for failing to raise the claim earlier and prejudice resulting therefrom or (2) that, due to the petitioner's probable innocence, a miscarriage of justice would occur if the claim were not adjudicated on the merits. Because the right to counsel extends to appeal, cause for the failure to raise a Padilla claim on direct appeal exists if appellate counsel's failure to raise the claim amounted to ineffective assistance of appellate counsel. Showing prejudice here requires showing a reasonable probability that the outcome of the appeal would have been different if appellate counsel had raised the issue-that is, a reasonable probability that the petitioner would have received relief on appeal for his Padilla claim. Petitioners who fail to raise the claim in state postconviction proceedings, however, will probably be unable to establish cause, because there is no right to the effective assistance of counsel in state postconviction proceedings. ${ }^{\text {6I }}$ The impossibility of success before Padilla was decided also fails to constitute cause for not raising the issue. ${ }^{62}$ As explained previously, a Padilla claimant's admission of guilt generally precludes any showing that he is probably factually innocent.

\section{E. Deference to State Decisions Under § 2254(d)}

State prisoners seeking federal habeas relief face one additional barrier: deference to state court determinations of law and fact. When federal courts review claims rejected on the merits by state courts, \2254(d) permits relief only when the state court's decision was "contrary to, or involved an unreasonable application of, clearly established law." ${ }_{3}$ A state court does not decide the merits of a claim when it rejects the claim as procedurally defaulted, filed in the wrong place or at the wrong time, or barred as a part of a successive petition. ${ }^{64}$ Merits decisions are reviewed for reasonableness, not correctness, and are judged by only "clearly established federal law, as determined by the Supreme Court of the United States." "Clearly established federal law" includes Supreme Court decisions establishing "whatever would qualify as an old rule under our Teague jurisprudence." ${ }_{5}$ In Padilla, the Court relied almost exclusively on its own precedents. Thus, for Padilla, a finding of retroactivity compels the conclusion that the rule therein became clearly established according to some pre-Padilla decision of the Court.

Federal courts, including those finding Padilla to be an old rule, have yet to grapple with the question of when the rule in Padilla became clearly established. The Court first applied Strickland to guilty pleas in the I98 5 decision of Hill v. Lockhart, holding that "the two-part Strickland v. Washington test applies to challenges to guilty pleas based on ineffective assistance of counsel." 66 It is Hill that clearly established the rule in Padilla.

Federal courts afford especially great deference to state court decisions denying relief based on applications of general rules such as Strickland. ${ }^{67}$ Section 2254(d) permits relief, however, where the state court decision rejecting the petitioner's constitutional claim was either "contrary to" or an "unreasonable application of" clearly established federal law. The Court has explained that the contrary to phrase applies when a state court "arrives at a conclusion opposite to that reached by [the Supreme] Court on a question of law or if the state court decides a case differently than [the Supreme] Court has on a set of materially indistinguishable facts." 68 A state court decision may meet the "unreasonable application" standard either (I) by "identif[ying] the correct governing principle from [Supreme Court precedent] but unreasonably appl[ying] that principle to the facts of the prisoner's case" 69 or (2) by "unreasonably extend[ing] a legal principle from our precedent to a new context where it should not apply (or unreasonably refus[ing] to extend a legal principle to a new context where it should apply)." 70

Many state decisions prior to Padilla applied the incorrect rule, a truncated version of Hill that excluded certain categories of advice as a matter of law rather than referring to prevailing professional norms. These decisions are much less likely to warrant deference. They may be characterized as either contrary to Hill because they applied the wrong test or unreasonable applications of Hill because they unreasonably failed to extend Strickland's case-by-case approach to all advice provided to a defendant who pleads guilty. ${ }^{7 \mathrm{I}}$ As for the content of professional standards, the Court itself appears to have foreclosed any argument that professional norms did not require such advice, at least for convictions final after I996.72

\section{F. Fact Finding, Evidentiary Hearings}

Two statutory provisions mandate deference to state court factual findings, such as findings about the existence and 
content of immigration advice. Section 2254(e) affords state court findings of fact a presumption of correctness, which the petitioner can only rebut "by clear and convincing evidence." Section 2254(d)(2) also provides that a court may grant relief when a state court's decision is "based on an unreasonable determination of the facts in light of the evidence presented in the state court proceeding."73

Because nearly every jurisdiction would previously have dismissed some or all Padilla claims as a matter of law, habeas petitioners are likely not to have developed an adequate factual record in state court. Where a petitioner has "failed to develop the factual basis of a claim in state court proceedings" by a "lack of diligence, or some greater fault," 74 the statute prohibits federal courts from conducting an evidentiary hearing, unless the petitioner shows that the facts underlying the claim show by clear and convincing evidence that "but for constitutional error, no reasonable factfinder would have found the applicant guilty of the underlying offense."75 Again, showing innocence will ordinarily be impossible for Padilla claimants, who have already admitted guilt. ${ }^{6}$ Where the petitioner diligently sought but was denied an evidentiary hearing in state court, a hearing may be granted or denied in the discretion of the district judge. 77

\section{Coram Nobis}

Habeas relief, in state or federal court, is available only to a petitioner who is still serving the sentence for the judgment he is attacking. Once a person is no longer in custody, he is no longer eligible to seek habeas relief or relief under $\int 2255$. He may, however, be able to challenge his conviction through the writ of coram nobis. ${ }^{78}$ Even removal from the country will not moot a coram nobis challenge because the conviction carries a continuing collateral consequence-the ongoing bar to reentry.79

A person convicted of a federal crime cannot obtain coram nobis relief unless he demonstrates a sound reason for failing to seek relief earlier. This standard is not as rigid as the one-year statute of limitations for $\ 2255$ filings. ${ }^{80}$ Nevertheless, an unexplained delay will bar relief for a Padilla claim that could easily have been raised earlier. ${ }^{8 \mathrm{r}}$ At least one petitioner has succeeded in securing coram nobis relief for a Padilla claim. ${ }^{82}$

Some states provide coram nobis relief from state convictions as well. Not all the states that offer coram nobis review will consider a Padilla-type claim. In California, for example, the writ of coram nobis is supposedly reserved for claims based on newly discovered facts, which would generally exclude Padilla claims for reasons discussed earlier. ${ }^{83}$

\section{Getting to the Merits: Establishing Ineffective Assistance}

If a petitioner manages to overcome these procedural barriers, he must demonstrate not only that his attorney's advice was unreasonable in light of professional norms but also that the deficiency was prejudicial. The second showing is particularly difficult, and many courts never reach the question of deficiency.

\section{A. When Is Counsel's Representation Deficient?}

The Court in Padilla noted:

When the law is not succinct and straightforward ... a criminal defense attorney need do no more than advise a noncitizen client that pending criminal charges may carry a risk of adverse immigration consequences. But when the deportation consequence is truly clear, as it was in this case, the duty to give correct advice is equally clear. ${ }^{84}$

Justice Alito, concurring, predicted that distinguishing between clear and unclear deportation risks will prove problematic. ${ }^{85}$ Although authority applying the Court's language is not well developed, some preliminary outlines are emerging. Included on the unclear side of the line, where general warnings suffice, are cases involving the probability of hardship waivers ${ }^{86}$ and cases involving misdemeanor offenses that might render the defendant subject to removal, such as crimes involving moral turpitude. ${ }^{87}$ Also presumably unclear are the immigration consequences in cases where the attorney general arguably retained discretion to withhold removal of a deportable noncitizen, a question that has produced splits in the lower courts and is the focus of a pending petition for review in the Supreme Court. ${ }^{88}$ One court has found no deficiency where the defendant represented in open court that he was willing to take his chances despite the uncertain possibility of deportation. ${ }^{89}$

On the other hand, vague warnings that the defendant may or might be subject to deportation are not sufficient where the defendant is clearly deportable. The Padilla Court itself stated:

Under contemporary law, if a noncitizen has committed a removable offense after the I996 effective date of these amendments, his removal is practically inevitable but for the possible exercise of limited remnants of equitable discretion vested in the Attorney General to cancel removal for noncitizens convicted of particular classes of offenses. $9^{\circ}$

Simply advising a client to seek outside immigration advice, without more, can also be deficient. $9^{\text {I }}$

Also left open is whether all immigration consequences must be addressed. At least one court has suggested that the failure to give advice on all three major immigration consequences-removal, naturalization, and exclusion-is deficient. ${ }^{92}$ But another court found sufficient a warning that the defendant would be barred from reentry, and did not mention removal or deportation specifically, where the defendant had been warned that "INS [could] start INS proceedings against him" whether or not he left the country. 93 


\section{B. When Is Deficient Representation Prejudicial?} Perhaps the most difficult hurdle for a defendant raising a Padilla claim is showing prejudice under Strickland and Hill—a reasonable probability that, but for counsel's errors, he would not have pleaded guilty and would have insisted on going to trial. In this context, prejudice requires an analysis of many factors: the chance of success at trial, the defendant's personal knowledge of any immigration consequences, any benefits accrued to the defendant by pleading guilty, and whether the defendant was otherwise deportable.

Even where counsel offers no advice about deportation, defendants will generally be made aware of possible consequences during the plea colloquy. Long before the Court decided Padilla, many federal and state judges were providing generic immigration warnings routinely. The federal Bench Book has at least since 2007 advised federal judges to ask noncitizen defendants before taking a plea, "Do you understand that your plea of guilty may affect your residency or your status with the immigration authorities?"94 Prior to 2010 , thirty states mandated some inquiry or warning regarding deportation consequences at the plea hearing. ${ }^{95}$ Where such a warning was given by the judge, a defendant alleging his attorney failed to advise him will be able to show prejudice only if he establishes that he did not believe the judge, that he lied when he stated in open court that he understood the judge's warning, or that the judge's warning did not convey the information he deserved to hear, because it was not as specific as the warning he should have received from his attorney. To date, most courts have not been particularly sympathetic to such claims, ${ }^{96}$ but there have been some exceptions. 97

A defendant who is able to make a credible claim of lack of knowledge must also establish that "a decision to reject the plea bargain would have been rational under the circumstances." ${ }^{8}$ The rationality of the decision turns in part "on the likely outcome of a trial had the defendant not pleaded guilty." 99 Given that immigration consequences are equally certain if a defendant is convicted of the same offense after trial rather than plea, and sometimes even more certain, ${ }^{100}$ a defendant must explain why a rational person would have believed he could have prevailed at trial. ${ }^{\text {IoI }}$ Courts properly reject allegations of prejudice when the defendant presents no strategy, defense, or basis for a jury to reject evidence of guilt.

Courts also view with skepticism claims that a defendant would have gone to trial where the defendant received a significant sentencing concession as a result of the plea. ${ }^{\mathrm{I}}{ }^{2}$ Allegations that the defendant would have rejected his plea deal and negotiated a deal that did not carry immigration consequences will only succeed if there is some proof that such a deal was available. ${ }^{\text {I03 }}$ Some courts have concluded that even if the defendant demonstrates a reasonable probability of acquittal, prejudice cannot be established so long as another independent basis for removal exists, such as an unchallenged conviction ${ }^{\mathrm{I0}}$ or drug addiction. ${ }^{105}$ Finally, a finding of possible prejudice, and a decision to hold a hearing on the issue, is more likely if the record suggests that the defendant was weighing the risk of deportation prior to entering the plea. ${ }^{106}$

\section{Conclusion}

Padilla will be available to petitioners who seek to challenge their convictions after their direct appeals, theoretically allowing a new round of challenges to guilty pleas that have long been final. Nevertheless, procedural hurdles such as filing deadlines and bars on successive petitions will allow courts to dispose of many Padilla claims without reaching the merits. Petitioners who manage to obtain review on the merits of their claim will face the daunting prospect of showing that an objectively reasonable defendant would have insisted on a trial. Although Padilla will probably result in an increase in prisoner filings, successful collateral challenges will be more of a trickle than the roaring stream of upset convictions evoked by the "floodgates" imagery.

\section{Notes}

* Special thanks to the Hon. Brian Owsley, the Hon. Hannah Lauck, and Tom Hanrahan for all they taught me.

** Special thanks to Susan Reilly for excellent research assis. tance.

$1 \quad 130$ S. Ct. 1473 (2010).

2 State v. Paredez, 101 P.3d 799, 803.04 (N.M. 2004); People v. Pozo, 746 P.2d 523, 527 (Colo. 1987) (en banc); State v. Arvanitis, 522 N.E.2d 1089, 1094.95 (Ohio Ct. App. 1986).

3 See, e.g., Sandoval v. INS, 240 F.3d 577, 578.79 (7th Cir. 2001); Roberti v. State, 782 So. 2d 919 (Fla. Dist. Ct. App. 2001).

4 See Denedo v. United States, 66 M.J. 114, 129 (A.F. 2008) (citing cases); Smith v. Gaither, 549 S.E.2d 351, 359 n.4 (Ga. 2001) (Sears, J., dissenting) (same).

5 Strickland v. Washington, 466 U.S. 668 (1984).

6 Hill v. Lockhart, 474 U.S. 52 (1985).

7 Padilla v. Kentucky, 130 S. Ct. 1473, 1482 (2010) (quoting Strickland, 466 U.S. at 688).

8 Id. at 1481 .

9 Padilla, 130 S. Ct. at 1481-82.

10 Dep't. of Homeland Sec., Yearbook of Immigration Statistics, tbl.38 (2010), available at http://www.dhs.gov/xlibrary/ assets/statistics/yearbook/2009/ois_yb_2009.pdf; Heather C. West, U.S. Dept. of Justice, Prisoner Inmates at Midyear, 2009_Statistical Tables, (June 2010, NCJ 230113), tbl.20, available at http://bjs.ojp.usdoj.gov/content/pub/pdf/ pim09st.pdf.

11 Some states had already required advice about deportation before plea prior to the Padilla decision. Brief of the Nat'l. Assoc. of Crim. Defense Lawyers et al. as Amici Curiae Sup. porting Petitioner at 1AA, Padilla v. Kentucky, No. 08.651, 2009 WL 1567356 (June 2, 2009). Cf. Carter v. State, 43 So.3d 907 (Fla. App. 2010) (affirming denial of motion alleg. ing lack of deportation advice from court, filed ten years past two-year window of State v. Green, 944 So.2d 208 (Fla. 2006), also noting defendant may file new motion under Padilla).

12 Lower courts already have extended the reasoning in Padilla to advice about other severe consequences of conviction traditionally considered collateral. See, e.g., Taylor v. State, 698 S.E.2d 384 (Ga. App. 2010) (sex offender registration); In re C.P.H., No. FJ-03-1313-02, 2010 WL 2926541 (N.J. Super. 
Ct. App. Div. July 23, 2010) (sex offender registration); Pennsylvania v. Abraham, 996 A.2d 1090 (Pa. Super. Ct. 2010) (loss of pension); but see United States v. Bakilana, No. 1:10 cr.00093 (LMB), 2010 WL 4007608 (E.D. Va. Oct. 12, 2010) (civil liability). Compare Ward v. State, 315 S.W.3d 461 (Tenn. 2010) (advice about mandatory sex offender registry not required, but advice was required concerning mandatory sen tence of community supervision for life). See generally Love \& Chin, Padilla v. Kentucky: The Right to Counsel and Collateral Consequences at Conviction, 34 Champion \#4, May 2010, at 18; Chin \& Holmes, Effective Assistance of Counsel and the Consequences of Guilty Pleas, 87 Cornell L. Rev. 697 (2002).

13 Wayne LaFave, Jerold Israel, Nancy King, \& Orin Kerr, Crimi. nal Procedure § 11.7(3) (3d ed. 2007 \& Supp.) (noting that allegations of one's own ineffectiveness is "most unlikely" and is viewed as placing lawyer in a conflict situation, requiring withdrawal).

14 See, e.g., State v. Romos, 787 N.W.2d 480 (lowa App. 2010) (appeal of denial of motion in arrest of judgment, finding that the record shows counsel's advice was sufficient, deny. ing request for evidentiary hearing on prejudice prong, and affirming conviction).

15 See, e.g., State v. Wilson, 31 S.W.3d 189 (Tenn. 2000) (defen. dant may not raise on appeal claim that guilty plea not knowingly and voluntarily entered, as such error would rarely be "apparent from a record of the proceedings already had," and thus proper forum is a postconviction proceeding).

16 See, e.g., Massaro v. United States, 538 U.S. 500 (2003); see also Thomas M. Place, Deferring Ineffectiveness Claims to Collateral Review: Ensuring Equal Access and a Right to Appointed Counsel, 98 Ky. L.J. 301 (2009-2010) (listing states that require new counsel to raise claim on direct appeal if appar. ent from the record, noting remand from the appellate court is available in at least four states, but that increasingly, states are deferring ineffectiveness claims to the postconviction process); Eve Brensike Primus, Structural Reform in Criminal Defense: Relocating Ineffective Assistance of Counsel Claims, 92 Cornell L. Rev. 679 (2007).

17 For example, the Supreme Court remanded for further consideration in light of Padilla, the 5th Circuit's rejection of a defendant's appeal of her guilty plea conviction. Chapa v. United States, 130 S. Ct. 3504 (2010). See also Brown v. United States, Nos. 1:10CV59, 1:07CR122-1, 2010 WL 3504805 (M.D. N.C. Sept. 2, 2010) (noting that 4th Circuit had rejected ineffectiveness claims on appeal and thus they were barred under $\S 2255$ ).

18 See United States v. Doe, 365 F.3d 150, 152 (2d Cir.2004) (remand is not the preferred response because, among other reasons, postponement until a § 2255 proceeding promotes judicial economy by allowing the district court to decide all of the defendant's collateral claims in one proceeding).

19 See Nancy J. King \& Michael E. O'Neill, Appeal Waivers and the Future of Sentencing Policy, 55 DukE L.J. 209 (2005).

20 See Vaca-Ortiz v. United States, 320 F.Supp.2d 1362 (N.D. Ga. 2004) (Section 2255 claim of ineffective assistance at sentencing barred by appeal waiver, distinguishing ineffective assistance surrounding the waiver itself); United States v. Guillen, 561 F.3d 527 (D.C. Cir. 2009) (upholding waiver of right to appeal effectiveness of counsel regarding sen. tence, distinguishing claims of ineffective assistance in agreeing to the waiver); People v. Williams,72 A.D.3d 1347 (April 22, 2010) (reversing lower court's decision that appeal waiver in plea agreement barred claim of ineffective assistance based on wrong advice about deportation, noting claim impacts the voluntariness of his plea, ordering hear. ing); LaFave et al., supra note 13 , at $\S 27.5$ (c), n.63 (noting a trend to enforce such waivers so long as the defendant is not claiming that substandard advice led to an unknowing or involuntary decision to sign the agreement containing the waiver).

21 See Alan Ellis \& Todd Bussert, Stemming the Tide of Postconviction Waivers, 25 CRIM. JUST. 28 (2010).

22 Teague v. Lane, 489 U.S. 288 (1989).

23 See, e.g., Danforth v. Minnesota, 552 U.S. 264 (2008); People v. Davis, 904 N.E.2d 149 (III. Ct. App. 1st 2009) (adhering to Teague); Ex parte Lave, 257 S.W.3d 235 (Tex. Crim. App. 2008) (same, although noting that it was "not required to do so" under Danforth); Mary C. Hutton, Retroactivity in the States: The Impact of Teague v. Lane on State Post-conviction Remedies, 44 AlA. L. Rev. 421 (1993).

24 Teague, 489 U.S. at 301.

25 Stringer v. Black, 503 U.S. 222, 228 (1992) ("The interests in finality, predictability, and comity underlying our new rule jurisprudence may be undermined to an equal degree by the invocation of a rule that was not dictated by precedent as by the application of an old rule in a manner that was not dictated by precedent.").

26 O'Dell v. Netherland, 521 U.S. 151, 160 (1997) (quoting Butler v. McKellar, 494 U.S. 407, 415 (1990)); see also Beard v. Banks, 542 U.S. 406, 413 (2004) (applying Teague and stat. ing that the issue is whether, at the time of the conviction, the "unlawfulness of [defendant's] conviction was apparent to all reasonable jurists").

27 Williams, at 410 (O'Connor, J., for the Court).

28 Williams v. Taylor, 529 U.S. 362, 390.392 (2000) (Strickland "provides sufficient guidance for resolving virtually all ineffective-assistance-of-counsel claims" unless fundamental fairness is an overriding consideration.); see also Newland v. Hall, 527 F.3d 1162, 1197 (11th Cir. 2008) (recent cases wherein the Court determined specific applications of Strickland were not new rules under Teague).

29 See Beard v. Banks, 542 U.S. at 413.

30 E.g., Martin v. United States, No: 09.1387, 2010 WL 3463949, at*3 (C.D. III. Aug. 25, 2010) (reaching same decision noting the Court's "emphasis on Strickland, prevailing professional norms, and the long recognized importance of the plea negotiation phase"); United States v. Chaidez, No. 03 CR 636.6, 2010 WL 3184150 (N.D. III. Aug. 11, 2010); Al Kokabani v. United States, No. 5:06-CR-207-FL, 2010 WL 3941836 (E.D.N.C. July 30, 2010) ( Teague analysis not accepted); United States v. Hubenig, No. 6:03-MJ.040, 2010 WL 2650625, at*7 (E.D. Cal. July 1, 2010) (observing that the Court apparently signaled that the holding would apply retroactively); People v. Garcia, 907 N.Y.S.2d 398, 400 (N.Y. Sup. Ct. 2010) (applying Padilla retroactively pursuant to New York's Teague-based rule; characterizing Padilla as application of Strickland).

But see United States v. Perez, No. 8:02Cr296, 2010 WL 4643033 (D. Neb. Nov. 9, 2010) (finding Padilla claim Teaguebarred); United States v Gilbert, No. 2:03cr439, 2010 WL 4134286, at*3 (D.N.J. Oct. 19, 2010) (offering nonretroactiv. ity as an alternative rationale for denying claim); People v. Kabre, 905 N.Y.S.2d 887, 893 (N.Y. Crim. Ct. 2010) (finding that Padilla is a new rule because the Court's observation in St. Cyr that competent counsel would offer immigration advice as appropriate was mere dicta and almost no other jurisdiction had so held, and because unlike Williams, Padilla mandated an unforeseeable change in the scope of counsel's representation); see also Haddad v. United States, Nos. 07-12540, 97.80150, 2010 WL 2884645, at *6 (E.D. Mich. July 20,2010) (characterizing as "unlikely" the chance that "Padilla will be made retroactive to convictions under collat. eral attack," but not deciding issue).

31 Hubenig, 2010 WL 2650625 at *5.8.

32 Williams v. Taylor, 529 U.S. 362, 391 (2000) (reversing where Supreme Court of Virginia erroneously concluded that the 
Strickland standard had been altered, and observing that the case-by-case evaluation of Strickland claims is itself "an old, well-established rule of law") (citing Rompilla v. Beard, 545 U.S. 374 (2005); Wiggins v. Smith, 539 U.S. 510, 522 (2003)).

33 See INS v. St. Cyr, 533 U.S. 289, 323 n.50 (2001) ("Even if the defendant were not initially aware of [subsequently excised] provision affording Attorney General discretion to allow deportable aliens to remain, competent defense coun. sel, following the advice of numerous practice guides, would have advised him concerning the provision's importance.").

34 Brief for the United States as Amicus Curiae Supporting Affirmance at 19, Padilla v. Kentucky, No. 08.651, 2009 WL 2509223 (August 17, 2009).

35 Hubenig, 2010 U.S. Dist. LEXIS 80179, 2010 WL 2650625, at *7 (quoting Padilla, $130 \mathrm{~S}$. Ct. at 1484-85).

36 Padilla, $130 \mathrm{~S}$. Ct. at 1486.

37 Whorton v. Bockting, 549 U.S. 406 (2007).

38 Whorton v. Bockting, 549 U.S. 406, 418.21 (2007). But see John L. Holahan \& Shauna Faye Kieffer, Effective Assistance of Counsel Where Pleas Mandate Deportation, BENCH \& BAR OF Minn. (Aug. 10, 2010), available at http://mnbenchbar.com/ 2010/08/padilla-motions/ (concluding that Padilla is a new watershed rule of criminal procedure).

39 Danforth v. Minnesota, 552 U.S. 264 (2008).

40 See Lasch, The Future of Teague Retroactivity, or "Redressability," After Danforth v. Minnesota: Why Lower Courts Should Give Retroactive Effect to New Constitutional Rules of Criminal Procedure in Postconviction Proceedings, 46 AM. CRIM. L. REv. 1 (2009). For a discussion of the pre-Teague standard most commonly applied, see LaFave et al., supra note 13 , at $\S$ 2.11(b)-(e) (discussing Linkletter standard).

41 Compare Ex Parte Moussazadeh, No. AP.76439, 2010 WL 4345740 (Tex. Crim. App. Nov. 3, 2010) (ordering briefing on issue of whether Padilla claim was barred under Teague) with Alaska v. Smart, 202 P.3d 1130 (Alaska 2009) (applying state rule that decided retroactivity of new rules based on three factors: (1) the purpose to be served by the new standards, (2) the extent of the reliance by law enforcement authorities on the old standards, and (3) the effect on the administration of justice of a retroactive application of the new standards); see also LaFave et al., supra note 13, at $\S 2.11(a)$.

4228 U.S.C. $\S \S 2244(d) ; 2255$ (f) (2010); Jiminez v. Quarterman, 129 S. Ct. 681,172 (2009) (period commences anew when state courts grant permission to file an out-of-time appeal). Tolling is also available during the pendency of a properly filed application for state postconviction relief . 28 U.S.C. $\S 2244(d)(2)(2010)$.

43 Antiterrorism and Effective Death Penalty Act of 1996, Pub. L. No. 104-132, 110 Stat. 1214.

44 See Allen v. Cooper, 276 F.3d 183 (4th Cir. 2001) (noting North Carolina courts apply the doctrine of laches); Moguel v. State, 966 A.2d 963 (Md. App. 2009); see also Donald E. Wilkes, State Postconviction Remedies and Relief Handbook with Forms 9.13 (3d ed. 2007-2008) (noting the District of Columbia and 20 states have no statute of limitations for filing the principal postconviction remedy in noncapital cases).

4528 U.S.C. $\S \S 2244 ; 2255$ (2010).

46 See Dodd v. United States, 545 U.S. 353, 358 (2005) (". . . Dodd points out that this Court rarely decides that a new rule is retroactively applicable within one year of initially recognizing that right. Thus, . . an applicant who files a second or successive motion seeking to take advantage of a new rule of constitutional law will be time barred except in the rare case in which this Court announces a new rule of consti. tutional law and makes it retroactive within one year.").
47 See note 38. See also United States v. Millan, Nos. 3:06cr458/ RV, 3:10cv165/RV/MD, 2010 WL 2557699 (N.D. Fla. May 24, 2010) (Padilla does not rest on a newly recognized rule that has been made retroactive and therefore petitioner was not excused from statute of limitations; petitioner did not dem. onstrate prejudice).

4828 U.S.C. $\S \S 2244 ; 2255$ (2010).

49 Holland v. Florida, 130 S. Ct. 2549 (2010).

50 Lower courts have so far assumed that the Supreme Court's decision also permits equitable tolling of the one-year period in $\S 2255$, see e.g., United States v. Sells, No. 10-7021, 2010 WL 3096064 (10th Cir. 2010).

51 Holland v. Florida, 130 S. Ct. 2549 (2010).

52 See Nguyen v. Van Boening, No. 10-cv-0249, 2010 WL 4553739 (W.D. Wa. June 2, 2010 (explaining that relying on Padilla deficiency to establish extraordinary circumstances in the wake of Holland is like "compar[ing] apples and oranges").

53 Holland v. Florida, 130 S. Ct. 2549, 2563 (2010). At least one court has also rejected equitable tolling of a Padilla claim because the petitioner failed to show reasonable dili. gence, Gacko v. United States, No. 09.CV.4938 (ARR), 2010 WL 2076020 (E.D.N.Y. May 20, 2010) (alternative rationale).

54 Compare Makic v. Smith, No. 4:07CV1577AGF, 2010 WL 3054892 (E.D. Mo. Aug 4, 2010) (Padilla claim time barred, rejecting equitable tolling), with Mendoza v. Carey, 449 F.3d 1065, 1070 (9th Cir. 2006) (non-English-speaking petitioner who was unable to obtain translation assistance despite diligent efforts might be able to establish the necessary extraordinary circumstances justifying equitable tolling).

55 Most states also restrict second or successive petitions.

5628 U.S.C. § 2244(b)(2)(A), § 2255 (h)(2) (2010).

57 In re Turner, 267 F.3d 225 (3d Cir. 2001); Lopez v. Douglas, 141 F.3d 974 (10th Cir. 1998); In re Jones, 137 F.3d 1271 (11th Cir. 1998).

58 The strength of the correlation between admissions of guilt and factual guilt is open to debate. See The Innocence Proj. ect, 250 Exonerated, Too Many Wrongfully Convicted, 36-37, available at http://www.innocenceproject.org/docs/ InnocenceProject_250.pdf (noting that 19 of the first 250 DNA exonerations were of people who pleaded guilty to crimes they did not commit).

5928 U.S.C. § 2244(b)(1) (2010).

60 LaFave et al., supra note 13, at §28.4(c).

61 Coleman v. Thompson, 501 U.S. 722 (1991).

62 See Bousley v. United States, 523 U.S. 614, 623 (1998) (cause not established where claim would have been futile because lower courts had rejected petitioner's legal position).

6328 U.S.C. $\S 2254$ (d)(1) (2010). Although similar, this standard is not identical to Teague. Horn v. Banks, 536 U.S. 266, 272 (2002) ("the AEDPA and Teague inquiries are distinct").

64 Medellin v. Dretke, 125 S. Ct. 2088, 2099-100 (2005) (O'Connor, J., dissenting) (procedural default); Boyd v. Way mart, 579 F.3d 330 (3d Cir. 2009) (claim rejected below as unexhausted); Thomas v. Horn, 570 F.3d 105, 115 (3d Cir. 2009); Simmons v. Beard, 590 F.3d 223 (3d Cir. 2009) (procedural requirements of state petition). See generally, 2 Hertz \& Liebman, Federal Habeas Corpus Practice and Procedure § 32.2, n.5.7 (1998).

65 Williams v. Taylor, 529 U.S. 362, 412 (2000).

66474 U.S. 52, 58 (1985).

67 See Knowles v. Mizayance, 128 S. Ct. 1411, 1420 (2009) (referring to the "doubly deferential judicial review that applies to a Strickland claim evaluated under the $\S 2254(d)(1)$ standard"); Yarborough, 541 U.S. at 664 ("[E]valuating whether a rule application was unreasonable requires consid. ering the rule's specificity. The more general the rule, the 
more leeway courts have in reaching outcomes in case-by case determinations."); Wright v. West, 505 U.S. 277 , 308.309 (1992) (Kennedy, J., concurring) (explaining that where the "rule in question is one which of necessity requires a case-by-case examination of the evidence, then we can tol. erate a number of specific applications without saying that those applications themselves create a new rule. . . . Where the beginning point is a rule of general application, a rule designed for the specific purpose of evaluating a myriad of factual contexts, it will be the infrequent case that yields a result so novel that it forges a new rule, one not dictated by precedent."); see also Renico v. Lett, 130 S. Ct. 1855 (2010) (finding reasonable the state court's application of the standard for reviewing mistrials upon deadlock-and noting that that standard-whether the judge exercised sound discretion- "is a general one, to which there is no "plainly correct or incorrect' answer in this case") (citing Yarborough, 541 U.S. 652).

68 Williams, 529 U.S. at 365.

69 Yarbrough v. Alvarado, 541 U.S. 652, 663 (2004).

70 Williams, 529 U.S. 362.

71 See, e.g., Banda v. United States, 1 F.3d 354, 356 (5th Cir. 1993) (quoting Brady v. United States, 397 U.S. 742, 755 (1970)); Santos v. Kolb, 880 F.2d 941, 944 (7th Cir. 1989); United States v. Campbell, 778 F.2d 764, 768 (1985) (quoting Wofford v. Wainwright, 748 F.2d 1505, 1508 (11th Cir. 1984) (alteration in original)).

72 Padilla, 130 S. Ct. at 1485 (explaining that "[f]or at least the past 15 years, professional norms have generally imposed an obligation on counsel to provide advice on the deportation consequences of a client's plea."); see also INS v. St. Cyr, 533 U.S. 289, 323 n.50 (2001).

73 The standard under $\S 2254(e)(1)$ is "arguably more deferen. tial" than that under $\S 2254(\mathrm{~d})(2)$, but the Court has declined to resolve how these two provisions "fit together," Wood v. Allen, 130 S. Ct. 841 (2010) (finding that even when reviewed under $\S 2254(d)(2)$, state court's determination that defense counsel made strategic decision not to pursue or present evidence of defendant's mental deficiencies was not unrea sonable in light of the evidence presented). Determinations of mixed questions of law and fact, such as whether immigration law was clear enough to trigger a duty to advise, or whether an objectively reasonable defendant would have insisted upon a trial, are not presumed correct under this standard. Strickland, 466 U.S. at 698.

74 Williams, 529 U.S. at 432 (diligence requires "a reasonable attempt, in light of the information available at the time, to investigate and pursue claims in state court.")

7529 U.S.C. § 2254(e)(2)(B) (2010).

76 See United States v. Lemaster, 403 F.3d 216, 221.22 (2005) (" $[\mathrm{I}] \mathrm{n}$ the absence of extraordinary circumstances, the truth of sworn statements made during a Rule 11 colloquy is conclusively established, and a district court should, without holding an evidentiary hearing, dismiss any $\S 2255$ motion that necessarily relies on allegations that contradict the sworn statements.").

77 Schriro v. Landrigan, 127 S. Ct. 1933, 1939-40 (2007).

78 Some courts may not be receptive to such motions, especially when they appear to circumvent restrictions on successive petitions. See, e.g., Melton v. United States, 359 F.3d 855, 857 (7th Cir.2004) ("Call it a motion for a new trial, arrest of judgment, mandamus, prohibition, coram nobis, coram vobis, audita querela, certiorari, capias, habeas corpus, ejectment, quare impedit, bill of review, writ of error, or an application for a Get-Out-of-Jail Card; the name makes no difference. It is substance that [makes it successive].").
79 Santos-Sanchez, No. 07-40145, 2010 WL 2465080 (5th Cir. June 15, 2010) (citing Zalawadia v. Ashcroft, 371 F.3d 292, 297 (5th Cir. 2004)) (a bar on readmission following removal or deportation is a legally cognizable collateral consequence, and thus deportation did not render habeas petition moot).

80 See, e.g., United States v. Hubenig, No. 6:03-mj-040, 2010 WL 2650625 (E.D.Cal. 2010) (granting coram nobis relief to Canadian citizen who had pleaded guilty to drug offense com. mitted in Yosemite National Park, finding that his claim that he was unaware of the immigration consequences of his guilty plea until the government began removal proceedings against him in late fall 2008 to be a valid reason for not seek. ing relief earlier, and refusing to dismiss petition noting that filing in April 2010 "within weeks of the Padilla decision" was sufficiently prompt, given that there was no showing of preju. dice to the government accruing between petitioner's discovery of the adverse deportation consequences in the fall of 2008 and filing his petition).

81 As Margaret Love and Gabriel Chin point out, the Supreme Court recently held in United States v. Denedo, 129 S. Ct. 2213 (2009), that Navy-Marine Corps Court of Criminal Appeals has jurisdiction to entertain a Nigerian national's coram nobis request challenging his military court conviction on the ground that he was erroneously reassured he could not be deported if he pleaded guilty. The Court expressly declined to address the merits of the claim, emphasizing only that "the writ of error coram nobis is an extraordinary writ" and "an extraordinary remedy ... should not be granted in the ordinary case." Id. at 2224 (citations omitted). Among the factors that should be explored on remand, it explained, were the "relative strength of respondent's ineffective-assistance claim, his delay in lodging his petition," and "when he learned or should have learned of his counsel's alleged deficiencies." Id. On remand, Denedo was denied relief on the basis that he could not show that the advice of his attorney prejudiced him. Id.

82 United States v. Chaidez, No. 03 CR 636-6, 2010 WL 3979664 (N.D. III. 2010) ("Taking Chaidez's testimony as the only evidence, and crediting in particular her testimony that the risk of some jail time was worth the chance to avoid deportation, the court finds that it would have been rational under the circumstances for Chaidez to insist on a trial."). Cf. United States v. Cruz-Veloz, Crim. No. 07-1023, 2010 WL 2925048 (N.J. July 20, 2010) (considering merits of Padilla claim on coram nobis, but finding no prejudice because peti. tioner was warned by the judge during the plea colloquy).

83 See People v. Cuatete, No. B218652, 2010 WL 1744891 (Cal. Ct. App. 2d, May 3, 2010) (noting court did not abuse its discretion denying writ of coram nobis when petitioner filed eight years after his conviction and failed to cite any newly discovered facts that qualify as a basis for the petition, but going on to evaluate failure to advise claim on its merits); see also People v. Barraza, No. H033755, 2010 WL 4252684 (Cal. Ct. App. 6th, Oct. 28, 2010).

84 Padilla v. Kentucky, 130 S. Ct. 1473, 1483 (2010).

85 Id. at 1487 (Alito, J., concurring).

86 See Diunov v. United States, No. 08 Civ. 3184(KMW), 2010 WL 2483985 (S.D.N.Y. June 16, 2010) (finding that the avail. ability of a section $212(\mathrm{~h})$ hardship waiver in the case of a nonlawful permanent resident "does not fall into that category of cases where the immigration law is sufficiently 'succinct and straightforward' such that an attorney would be, under Padilla, under an affirmative duty to advise his client").

87 Many of these cases appear to involve pleas to misdemean. ors, including failed efforts in drug courts, see, e.g., Flores v. State, No. 4D08-3866, 2010 WL 2882465 (Fla. Dist. Ct. App. 
4th July 14, 2010); People v. Cristache, 907 N.Y.S.2d 833 (N.Y. Crim. Ct. Sept. 13, 2010) (noting crimes to which petitioner pleaded were not the "automatic" kind because he was sentenced to less than a year, but finding that Padilla required that when the removal consequences were "unclear or uncertain" counsel was constitutionally obliged to "do no more than advise [him] that pending criminal charges may carry a risk of adverse immigration consequences").

88 A petition for certiorari is pending, asking the Court to resolve a question about which crimes are "particularly serious crimes," conviction of which terminate eligibility for withholding of removal. Gao v. Holder, No. 10-130, 2010 WL 2912534 (July 22, 2010). The interplay between state crimi nal law and federal immigration consequences can generate uncertainty. See, e.g., Caruchi-Resendo v. Holder, 130 S. Ct. 2577, 2589 (2010) (holding that, even where factual basis would have supported conviction for federal felony, defendant must actually be convicted of a state "crime that is itself punishable under federal law" for purposes of revocation of eligibility for withholding of removal).

89 Nguyen v. state, No. A10.436, 2010 WL 4608348 (Minn. App. Nov. 16, 2010).

90 Padilla, 130 S. Ct. at 1479.

91 People v. Garcia, 907 N.Y.S.2d 398 (N.Y. Sup. Ct. 2010) (deficient advice to advise client he should seek outside immigration advice, without more, at least where the immigration implications of the plea were fairly straightforward, and where the "specialist's" advice was wrong); but see Chhabra v. United States, No. 09cv1028, 2010 WL 4455822, at $* 5$ (S.D.N.Y. Nov. 3, 2010) (no prejudice where defendant subsequently obtained competent advice from immigration attorney); Diunov v. United States, No. 08 Civ. 3184(KMW), 2010 WL 2483985 (S.D.N.Y. June 16, 2010). Other observers have commented on the problem of erroneous immigration advice offered by notarios and similar nonpractitioners. Gary Rivlin, Dollars and Dreams: Immigrants as Prey, N.Y. TIMES, June 11, 2006, at B1.

92 People v. Olide, No. F059034, 2010 WL 3419698 (Cal. Ct. App. 5th Aug. 31, 2010) (when left out exclusion but warned about deportation and naturalization, error, but no prejudice shown).

93 People v. Mills, 28 Misc.3d 1236(A), 2010 WL 3619858, at *2 (N.Y. Crim. Ct. 2010) (warning that defendant might be barred from reentry was sufficient and that the successive motion did not allege facts that were not or could not be con. sidered in earlier motion).

94 Federal Judicial Center, Benchbook for U.S. District Court Judges, at 75 (5th ed. 2007), available at http://www.fjc.gov/ public/pdf.nsf/lookup/Benchbk5.pdf/\$file/Benchbk5.pdf.

95 Brief of the Nat'l. Assoc. of Crim. Defense Lawyers et al. as Amici Curiae Supporting Petitioner at 1AA, Padilla v. Kentucky, No. 08-651, 2009 WL 1567356 (June 2, 2009); see generally Uniform Collateral Consequences of Conviction Act (proposed 2010 amended version).

96 Finding no prejudice because of judicial warning, State v. Bains, No. 94330, 2010 WL 4286167 (Oh. App. Oct. 21, 2010); Al-Kokabani v. United States, Nos. 5:06-CR-207-FL, 5:08.CV.177.FL, 2010 WL 3941834, at*3-4 (E.D.N.C. Oct. 7, 2010) (no prejudice where counsel warned of deportation consequences if sentence exceeded twelve months and trial judge warned of statutory maximum greater than one year); see also Gonzalez v. United States, Nos. 10 Civ. 5463(AKH), 08 Cr. 146(AKH), 2010 WL 3465603 (S.D.N.Y. Sept. 3, 2010); Momah v. United States, Nos. 4:10-CV-369-A, 4:07.CR-189-A, 2010 WL 3431657 (N.D. Tex. Aug. 30, 2010); United States v. Cruz-Veloz, Crim. No. 07-1023, 2010 WL 2925048 (N.J. July 20,2010) (considering merits of Padilla claim on coram nobis, but finding no prejudice because of judicial warnings); Flores v. State, No. 4D08.3866, 2010 WL 2882465 (Fla. Ct. App. 4th July 14, 2010) (arrested when failed to complete drug court, entered plea and sentenced to time served, filed 3.850 motion to withdraw plea once ICE came after him, finding no prejudice when advised by judge during colloquy, rejecting claim that he did not believe this applied to him and believed his lawyer instead, stating "A defendant's sworn answers during a plea colloquy must mean something. A criminal defendant is bound by his sworn assertions and cannot rely on representations of counsel which are contrary to the advice given by the judge."); Ellington v. United States, No. 09 CIV 4539(HB), 2010 WL 1631497 (S.D.N.Y. April 20, 2010) (finding no prejudice when the petitioner answered "Yes, sir" to judge's question at plea colloquy asking whether he understood that plea "may affect" his "ability to remain within the United States"); see also People v. Contant, ... N.Y.S.2d …, 2010 WL 4243191, at *2 (N.Y. App. Oct. 26, 2010) (judge's warning did not mislead petitioner into believing that immigration consequences might not occur).

97 People v. Garcia, 907 N.Y.S.2d 398 (N.Y. Sup.2010) (rejecting Bhindar, Zhang, Ellington, Boakey, Hernadez-Monreal, and Mendoza v. Wynn, finding that where defendant is misled by bad advice from a so-called retained specialist and by lack of advice from his defense attorney, the court's general warning will not automatically cure counsel's failure nor erase the consequent prejudice, and, standing alone, should not be given conclusive and dispositive effect on the issue of prejudice). State courts may also provide more generous relief, Brief of Defendant-Appellant, Wisconsin v. Hernandez-Morales, No. 2010AP1459.CR (Wis. Ct. App. 3d Sept. 7, 2010) (citing State v. Douangmala, 646 N.W.2d 1 (2002)) .

98 Padilla, 130 S. Ct., at 1485.

99 Meyer v. Branker, 506 F.3d 358, 369 (4th Cir. 2007).

100 People v. Picca, 908 N.Y.S.2d 565 (N.Y. Sup. Ct. 2010) (finding no prejudice from failure to advise when evidence of guilt was compelling and conviction after trial meant certain deportation and a sentence of up to twenty-five years, whereas "no confirmed evidence that anyone who has ever successfully completed a court mandated treatment program and had the case dismissed and sealed, as would have occurred here, has ever been deported based on the plea alone"); see also United States v. Denedo, No. NMCCA 9900680, 2010 WL 996432, at *5 (N.M. Ct. Crim. App. March 18, 2010) (approving of counsel's advice, noting "Contesting the charges at a general court-martial with no conceivably valid defense would almost certainly have led to a significantly more calamitous result for the petitioner," and that it unlikely that a rational accused would have insisted on trial).

101 United States v. Babalola, 248 F.App'x. 409, 413 (3d Cir. 2007).

102 See, e.g., Andrews v. United States, Nos. 1:09Cv960, 1:07CR232-1, 2010 WL 3243342 (M.D.N.C. Aug. 16, 2010) (finding no prejudice where petitioner did not demonstrate that some possible strategy existed upon which a reasonable defendant would have gone to trial to face a 165 -month sentence); see also People v. Cristache, 907 N.Y.S2d 833 (N.Y. Crim. Ct. 2010) (defendant "unquestionably would have been placed in greater jeopardy of removal had he been convicted after trial," advanced no viable defenses, and maintained that if he had been warned appropriately, he would have sought a more favorable plea, not trial); see also Boakye v. United States, No. 09 Civ. 8217, 2010 WL 1645055 (S.D.N.Y. April 22, 2010) (defendant could not show prejudice when he faced extensive evidence of guilt, received a thirty-month decrease in the minimum guideline range, and had indicated 
that he desired to leave the country); People v. George, 28 Misc.3d 1232(A), 2010 WL 3516072 (N.Y. Crim. Ct. 2010) (no prejudice when defendant avoided incarceration by accepting time served)

103 See United States v. Hubenig, No. 6:30-mj-040, 2010 WL 2650625 (E.D. Cal., July 01, 2010).

104 Ellington v. United States, No. 09 CIV 4539(HB), 2010 WL 1631497 (S.D.N.Y. April 20, 2010) (noting state convictions would still render petitioner ineligible for reentry).

105 See People v. Cristache, 907 N.Y.S.2d 833 (N.Y. Crim. Ct. 2010) (dicta) (citing 8 U.S.C. $\S 1227(a)(2)(B)(i i)(2010)$ ) (noting even with acquittal, defendant would have "remained at risk of removal because his long-standing drug addiction constitute[s] an independent ground for removal"). In our view, this reasoning improperly narrows the concept of prejudice. To show prejudice from his counsel's deficient advice about the choice between plea and trial, a defendant need show only that opting for trial after receiving the correct advice would have been a rational decision. Avoiding conviction and the certain deportation that would result can certainly be a rational choice, even if deportation for other reasons remains a risk

106 Compare People v. Picca, 908 N.Y.S.2d 565 (N.Y. Sup. Ct. 2010) (distinguishing and collecting cases) with People $v$. Ortega, 29 Misc.3d 1203(A), 2010 WL 3786254 (Table) (N.Y. Crim. Ct. 2010) (ordering a hearing on the issue of prejudice without first analyzing strength of evidence or probable trial sanctions) and People v. Paredes, 29 Misc.3d 1202(A), 2010 WL 3769234 (Table) (N.Y. Sup. Ct. 2010) (same). 